Preprint. Final version appears as:

Morgan, R.M \& Bull, P.A. (2007) The philosophy, nature and practice of forensic sediment analysis.

Progress in Physical Geography. DOI 10.1177/0309133307073881

\title{
The philosophy, nature and practice of forensic sediment analysis
}

\author{
Ruth M. Morgan and Peter. A. Bull \\ Oxford University Centre for the Environment, University of Oxford, South Parks \\ Road, Oxford, OX1 3QY
}

Communicating author: Ruth Morgan

ruth.morgan@ucl.ac.uk

Tel: +442031083037

Fax: +442031083088 


\title{
The philosophy, nature and practice of forensic sediment analysis
}

\author{
Ruth M. Morgan and Peter. A. Bull \\ Oxford University Centre for the Environment, University of Oxford, South Parks \\ Road, Oxford, OX1 3QY
}

\begin{abstract}
The rapidly expanding field of forensic geoscience derives its roots from $19^{\text {th }}$ and early $20^{\text {th }}$ Century scientists who both influence and are influenced by literature and fictional writing. Forensic geoscience borrows much, but not all, of its precepts from geological and geomorphological analytical techniques.

Fundamental differences exist between forensic geoscience and its sister disciplines, fundamental enough to make the unwary geoscientist succumb to philosophical and practical pitfalls which will not only endanger the outline of their report, but may well indeed provide false-negative or false-positive results leading to contrary or wrongful conclusions. In the law, such outcomes have devastating and untenable consequences.
\end{abstract}

Forensic geoscience requires techniques of exclusion rather than inclusion and an acknowledgement that analytical techniques may be diagnostic only in very specific situations. Whether analysis of the ubiquitous or the exotic component is chosen, acknowledgement of the need for samples to be representative is required. The presentation of false-positive results or the lack of identification of sample 'contamination' is prerequisite to the application of statistical tests which must be applied in the most careful manner. The realisation of the limitations of the technique requires, wherever possible, conjunctive analysis by other truly independent techniques. Whilst personal opinion derives from experience, there is no place for assumption. Research papers in forensic geoscience are not submitted to be speculative or challenging as may be the case in many fields of geomorphology and geology. There is no place for conjecture in forensic geoscience.

Keywords: Forensic geoscience; geology and geomorphology; philosophy; application of forensic sediment analysis. 


\section{Introduction: Setting the Scene}

The field of forensic geoscience involves criminal and civil investigations utilising the disciplines of geology, geomorphology, botany, biology and statistics. Investigations can take place at the macro scale of satellite imagery and GIS through to the micro scale analysis of trace materials including soils and sediments and DNA analysis. Criminal investigations utilise descriptive and predictive methodologies of both recent and more ancient (mass graves and other archaeological investigations) occurrences. Whilst this review introduces one of the most rapidly expanding disciplines within both the forensic and geoscience arenas, the main point to be stressed is that there is no easy philosophical or practical transition from geoscience to the forensic discipline.

Forensic geoscience and physical geography/geology utilise the same information, but the philosophical approach of the two could not be more contrasting. It would be difficult to imagine a discipline within geomorphology or geology which based its published research upon personal opinions. These personal interpretations are not peer-reviewed but rather are judged on general public understanding and acceptance (by judge and jury) in a court of law. This indeed is the case in forensic geoscience interpretation and presentation.

A current debate in the scientific literature (medical) suggests that many published research findings are false (Ioannidis 2005) and that even if the paper is itself factually correct, problems with experimental and statistical analysis determine that there is only '... a 50\% chance that the results from any randomly selected scientific paper are true' (Kleiner 2005). However, scientific papers may provide an intriguing insight into the possibility for further analysis even if the actual factual material is flawed. As Solomon Snyder, senior editor for the Proceedings of the National Academy of Sciences has said (quoted by Kleiner (2005)) '... when I read the (scientific) literature, I'm not reading it to find proof like a textbook, I'm reading to get ideas. So even if something is wrong with the paper, if they have the kernel of a novel idea, that's something to think about'. All of the above critiques refer to medical trial results, but they do provide a very important message for the practitioners of forensic geology, geomorphology and other geosciences. Whilst it is 
possible to accept or even encourage experimental publication in many branches of science (including physical geography), it is simply not feasible to introduce such a liberal attitude into the forensic arena. The acceptance of a scientific technique in forensic enquiry is not only through publication (and peer-review), but also in the courtroom. The judge will decide the admissibility of evidence, although it is the jury, that body of twelve lay-persons (who are not necessarily conversant with scientific theory or even jargon), who must be led through the intricacies of geoforensics (or any other scientific discipline) pertinent to the case.

The jury are a susceptible body of individuals who may well be influenced subliminally by the remarkable successes of forensic investigation portrayed in the media, and particularly television, through programmes such as 'CSI'. In these programmes, not only is the scientific method up-to-date, it is quick, efficient and provides unequivocal results which rarely, if ever, seem to be wrong. The idea of inaccurate or contradictory results, or even of some unidentified false-positive findings never seem to appear in the script. Thus the expectation of some jury members that forensic science can not be wrong is unfounded.

The forensic expert may also introduce bias into the courtroom. Many forensic geoscientists provide the same results whether they are acting as a prosecution or a defence expert. Some forensic experts do tend to get carried away with the situation and, egged on somewhat by an enthusiastic barrister, can be induced to provide interpretations that go beyond reasonable scientific interpretation of the evidence. Sometimes the expert makes assumptions or judgements 'based on their experience' and most certainly not based upon a fair interpretation of their results. This highlights a difference between forensic enquiry and that of a geological or geomorphological study. Personal opinion seems to be accepted by the courts far more than it would be in the geological literature. Recent newspaper cases, of course, highlight the fate of the forensic expert if their personal opinions are proven subsequently to be wrong (BBC news 2005).

Perhaps one of the fundamental differences between forensic geoscience and the disciplines of physical geography and geology is in the philosophical approach adopted by each set of practitioners when investigating a situation. The physical 
geographer will often strive to reconstruct palaeoenvironment or indeed, modern day environment by identifying similar trends and similar characteristics in order to match or group characteristics of a soil, sediment or landform. The forensic geoscientist can not match samples, rather, they seek to exclude one sample from having derived from the same source as a comparator sample. Thus, it is easier and more viable to exclude soil adhering to shoes or clothing of a suspect with that of a murder scene or body disposal site. That these two samples appear to have similar characteristics can not mean that have derived from the same site, merely that the samples can not be excluded from having derived from the same site. This is the fundamental difference in approach between the forensic geoscientist and the more conventional practitioner of physical geography and geology. Although speculative research papers are profitably published in geological and physical geography journals, they are not used to reinforce the methodology and results obtained, say in landscape management consultancy. They run parallel to the practical applications of the applied nature of the subject. Such speculative research papers in forensic journals, however, would be more problematic. There would be the temptation to justify a new methodology and hence results obtained from such an experimental study as established theory and thus be deemed appropriate by the judiciary in the court arena.

The influence of modern day television upon forensic practice, as described above, may well apply, but such influence is most certainly not a modern day phenomena. The late nineteenth century gave rise to the famous adventures of Sherlock Holmes written by Sir Arthur Conan Doyle (1887-1917), popular novels by Samuel Clemens writing as Mark Twain (1894) and R. Austin Freeman's scientific detective Dr John Evelyn Thorndyke. These all had a demonstrable influence on the way in which the early police forces conducted their scientific enquiries. Conan Doyle introduced his scientific logic into hypothetical cases solved by Sherlock Holmes (and even used his skill in a real life situation where he successfully conducted an appeal against a wrongful conviction). Conan Doyle concerned himself with geological matters throughout his books and there have been many commentaries written referring in detail to his methods (Sarjeant 1994, Campbell 2001). Perhaps the most overlooked work is that by R. Austin Freeman who portrayed his hero Thorndyke as a man of considerable geological knowledge and technique (Freeman 1925). All of these popular novels had much influence upon the development of modern criminal 
investigation. Indeed, one of the founding fathers of anthropometric forensic investigation, Alphonse Bertillon, is quoted as saying 'I would like to see Sherlock Holmes' methods of reasoning adopted by all professional police' (Berg 1970: 447). Edmond Locard, who produced the seminal theory now abbreviated as 'every contact leaves a trace' (Locard 1930) and as such has so influenced modern day forensic investigation, acknowledged his debt to Conan Doyle's work by commenting that 'Sherlock Holmes was the first to realise the importance of dust. I merely copied his methods' (Berg 1970: 448). A twist in this tale may be that Hans Gross who published a book 'Criminal Investigations' (1893) which outlined the practical application of scientific principles to forensic enquiry may well have been the inspiration for Conan Doyle who had read early editions of Gross's textbook. The historical commentary of today suggests that Gross actually received his ideas from Doyle following the first Sherlock Holmes story (A Study in Scarlet) in December 1887, some six years before Gross's seminal work was published.

In order, therefore, to understand the importance of geoscientific influences upon the forensic arena we must consider the differences between the philosophical approaches of the two disciplines and the strange historical influences of art on science both at the end of the $19^{\text {th }}$ and the end of the $20^{\text {th }}$ Century. Perhaps between these two periods of time, scientific advancement could be accredited as leading the art of media, fiction and the whodunits.

\section{The Development of Ideas in Forensic Sediment Analysis}

Following on from the pioneering influences of the literary writers and from the nineteenth century 'search for identity' (reviewed in Beavan 2002 and Sengoopta 2004), which resulted in the development and utilisation of fingerprints in forensic criminal investigation, a period of data accumulation rather than innovation took place in forensic enquiry. This consolidation is exemplified by the work of Popp who was a chemist by training and had the ability and initiative to use new applications for the scientific techniques which were rapidly becoming available at the time (Murray and Tedrow 1975). In 1904, Popp solved the murder case of Eva Disch by examining the mineralogy of the soil taken from the trousers of the suspect and comparing it to the soil taken from the place that the victim's body had been found. He found these 
mineralogical profiles to be comparable (he could not exclude them from having derived from the same source). Thus a geoscientific mineral study had been used to help solve a real case, fulfilling the predictions of Gross and further illustrating the foresight of Sherlock Holmes' creator. Furthermore, Edward Heinrich (a professor of criminology at Berkeley, California) developed a reputation for being able to use physical evidence to assist criminal investigations in the 1920s

These early harbingers contributed to the beginning of the development of forensic science by providing means of personal identification. The discipline has advanced from these foundations to provide the ability to establish the provenance through the development of techniques to analyse and compare at least two samples for individual characteristics. It was, therefore, with the provision of Locard's exchange principle (Locard 1930), that the possibility of the value of trace physical evidence came to be established. He believed that a criminal could not visit a crime scene without leaving behind or taking away some form of trace material (Houck 2001), as '...the microscopic debris that cover our clothes and bodies are the mute witnesses, sure and faithful, of all our movements and of all our encounters' (Locard 1930: 276). Similarly, Kirk (head of the first official school of criminology in the USA in 1948) advocated the high value of trace physical evidence, explaining that while '...gross physical evidence is valuable and must receive full attention, it will often be absent. Microscopic evidence is present in most cases and is therefore of much wider availability' (Kirk 1974: 3). In 1932 the Bureau of Investigation (re-named the FBI from 1935) was established in Washington D.C. With the use of specialised microscopes and extensive reference collections for comparisons it assisted Federal and local investigations. The microscopic comparisons of hairs and fibres were soon followed by glass, paint and soils.

Although this period was one of data accumulation rather than interpretative innovation, some significant inventions precipitated new lines of forensic enquiry. Worldwide, laboratory techniques developed as microscopy developed. The invention of the comparison microscope by Gravelle in 1925 revolutionised the comparisons of trace material by allowing two items to be observed simultaneously. More recently, electron microscopes have been increasingly used. The transmission electron microscope (TEM) allowed the study of the surface of a particle by means of 
a replica or section. This has been superseded in the 1960s by the scanning electron microscope (SEM) which is able to provide high resolution, relatively large depth of focus images of the surfaces of particles, with very high magnifications. In geoforensic work the TEM and SEM are used very successfully to look at a whole manner of trace materials, at last allowing true inspection of the exchange principle and verifying the work of Locard.

The well cited book 'Forensic Geology' (Murray and Tedrow 1975 with a subsequent edition in 1992) summarises many case studies and advances made in the field of forensic geoscience in the latter part of the twentieth century. From this work came the realisation amongst geoscientists that their particular fields of research were applicable to forensic investigations. And so forensic casework now includes investigations from gross landscape studies, archaeology, GIS and satellite investigations (Ruffell and McKinley 2005, Hunter et al 2001), micropalaeontology (although this was first used by the fictional detective Thorndyke in 1916 (Freeman 1916)), botanical and palynological studies (Miller Coyle 2004), and mineralogical and geochemical investigations (see the various papers collated in Pye and Croft 2005 and by Bull and Morgan 2005. See also figure 1).

More recently forensic geoscience has embraced the use of DNA analysis to investigate the constituent parts of soil and sediment (Carita 2004, Miller Coyle ed) and with a growing database, this subdiscipline will become of increasing importance in the next few years. Allied to this development is forensic pollen analysis, first summarised by Moore et al (1991) together with the more embracing concept of 'environmental profiling' pioneered by Wiltshire (2002) which considers not only pollen analysis but the whole spectrum of plant assemblages, and these have proven to provide not only comparative but predictive forms of evidence.

Perhaps the last word regarding the development of ideas in forensic sediment analysis can be left to the International Association of Forensic Science, who in their recent conference published in excess of 800 papers in abstract form (Beh 2005) which comprehensively review not only the present state of play in forensic geoscience but of forensic geoscience as a whole. 


\section{The Philosophy of Forensic Geoscience}

The basic precepts of the philosophy of forensic geoscientific investigation can be summarised as such:

1. The requirement to exclude rather than to match samples or scenes.

2. The descriptive, exclusionary and diagnostic nature of analytical techniques.

3. The necessity to use independent forensic techniques.

4. The balance between the 'exotic' and the 'ubiquitous'.

\section{The exclusion of samples}

The fundamental aim in forensic geoscience enquiry is to exclude samples from having derived from a scene or a person. This contrasts markedly with the geological approach which normally seeks to identify and classify samples according to their similarity. Thus, forensic geoscience techniques will tend to be descriptive and/or exclusionary but only sometimes diagnostic in nature. Very few techniques fall into the latter category since to be truly diagnostic there must exist at least a sample database which will then enable a statistical appraisal of the derived results.

\section{Descriptive versus diagnostic}

Descriptive techniques include those such as the colour of a soil or sediment sample. In geological analysis this is usually undertaken by using a Munsell colour chart or by automatic measures using some form of spectrophotometer. Thus, a sample can be designated as having a colour attributed to a particular class and hue which can then be used in comparison to another sample. Sugita and Marumo $(2001,1996)$ are much quoted as proponents of colour analysis for the differentiation of samples in forensic investigations. They seek to differentiate (or indeed exclude) samples based on colour much in the way that Conan Doyle did in 1906-7 when he moved from writing fictional stories of Sherlock Holmes to taking on the case of George Edalji. This forced the British government to take action and release the wrongfully imprisoned Edalji, when he successfully proved that the mud found on the shoes of the accused was of a markedly different colour to that at the scene of the crime. In such a case, the descriptive technique proved to be exclusionary. The main problem however, 
with the routine analysis of samples for colour differentiation is that of 'contamination' of the sample pre- or post-forensic event. Visual inspection may identify different layering of mud and hence different colour banding indicating a mixture of soil sources, but if layering is not present it would not be possible to determine whether the sample was indeed an admixture. The analysis of colour generally requires the homogenisation of the sample by grinding the material to a fine powder (for the production of a pellet or solution) for analysis. Such homogenisation removes any possibility of being able to safeguard proper comparison and exclusion between samples since there is no possibility of identifying mixing and hence, the possible production of false-positive or false-negative results.

Similarly, particle size analysis, the useful basic tool in sedimentological investigations, can be used as a descriptive, and on occasion, as an exclusionary technique. Samples that produce the same cumulative curves of particle size distribution may be deemed to be similar to each other and may be considered to have derived from similar source or type of source. This simple step is often undertaken as a descriptive tool in geological investigations but would be foolhardy to do so in forensic casework. The shape of the cumulative curve of particle size distribution of a sample may reflect hydrological or palaeohydrological conditions prevailing during the transportation phase of a sediment in water or wind prior to its deposition. Equally, some of the constituent materials could have been derived from gravity-fed sediment, or in the case of forensic enquiry, from anthropogenic sources and so affecting the final particle size distribution. Particle size analysis is usually employed in geological investigations as a descriptive tool for soils and sediments. However, in forensic enquiry, samples analysed by grain size analysis often involve testing materials which have been introduced as a result of walking or running. Thus, soils and sediments transported from, and to, a scene normally occur on footwear or clothing. Such transportation mechanisms introduce the complicated factors of sediment mixing, transfer and the persistence of materials. These are indeed complicated additions to be taken very carefully into consideration before two grain size distribution curves of sediment or soil can be compared and excluded from each other (Morgan and Bull 2006).

\section{The use of independent techniques}


In order to identify the provenance or exclusionary nature of a soil or sediment sample the array of analytical techniques employed should include techniques which are not dependent upon each other for their end result (see figure 1). So for example, the colour of a sample may well be directly associated with the mineralogical composition of that sample and indeed, the chemical make-up of that same sample (perhaps analysed by ICP analysis). These three lines of enquiry may well provide similar associations or exclusions of samples, however, since they are not independent of each other, their use as corroborative evidence may be highly questionable (not withstanding the problems of homogenisation and 'contamination' as outlined above). If on the other hand, the mineralogy of a sample is assessed in conjunction with the palynological profile of palynomorphs found within that sediment (Miller Coyle 2004, Wiltshire 2002, Bryant et al. 1990), then similar resulting conclusions will hold more significance in exclusionary studies due to the independence of these two analytical techniques (Morgan et al. 2006).

\section{Exotic versus ubiquitous}

The last philosophical dilemma that faces a forensic geoscientist is whether to use the ubiquitous characteristics of a sample for analysis, or to search for its rarer, more 'exotic' components. Both approaches are, under different situations, perfectly valid, but of course present their own representative pitfalls. The ubiquitous characteristics of a sample may be purely descriptive in nature and not at all exclusionary or diagnostic due to their common form. Perhaps one of the exceptions to this rule is the study of quartz grain surface textures (Bull and Morgan 2006 in press) which utilises the ubiquitous nature of quartz, the most common detrital mineral, but identifies and classifies the surface textures found on the surface of each grain utilising the technique pioneered by Krinsley and his co-workers initially in the 1960s and early 1970s (Mahaney 2002, Bull 1981, Krinsley and Doornkamp 1973). Similarly, the presence of common but restricted assemblages of minerals in a soil may well highlight exclusionary or diagnostic sediment provenances (Morgan et al. in press).

The identification of the 'exotic' sample or component of a soil or sediment is to some extent the holy grail of forensic geoscientific enquiry. Many reports of actual case work samples include the identification of exotic materials. These are normally of anthropogenic origin and can prove extremely important in the courtroom. Many 
such cases are provided by Murray and Tedrow (1992) in their excellent review of the application of forensic geology to criminal investigation. Palynological examples of exotic materials are also reported by Mildenhall (1988), Bryant and Mildenhall (1998) Horrocks et al. (1999) and provided in references in figure 1. The problem of searching for exotic materials for comparative studies, is that by their very nature they are found in very low concentrations and may not be represented in two samples taken at the same source site, thus providing the possibility of a false-negative exclusion.

In the search for the resolution of the restrictive nature of ubiquitous or exotic components of a sample, it is perhaps important to recognise what is not present in the sample which would normally be expected to be found. The introduction of exotic species of trees and plants as often popularised by the Georgian and Victorian gentry, result in the near ubiquitous nature of Horse Chestnut (Aesculus) pollen in urban British soils since the $18^{\text {th }}$ Century. A terrorist case arose where the accused were purported to have dug a hole to a depth of about $1 \mathrm{~m}$ in an undisturbed area of pasture land near Heathrow airport. The spades used to dig the hole were transported back to a garage, in Hampstead, where they were left whilst a recently assembled mortar device was taken from the garage and placed in the hole. Lumps of mud which had fallen from the spades were found to contain an apple orchard and heathland pollen assemblage which was of similar palynomorph composition to soils sampled at the site where the hole had been dug. Mud samples taken from the garage and from the base of the hole were found to be both deficient in Horse Chestnut pollen. Since the Horse Chestnut had not been introduced in any numbers into Britain until the beginning of the $19^{\text {th }}$ Century, the lack of pollen indicated that the lumps of mud in the garage may have derived from the base of a soil profile (i.e. a hole) which predated the introduction of the Horse Chestnut tree into the area. Though not a diagnostic result, it provides a good example of the importance to search not only for what is present, whether it be in large or small amounts, but also for what is not present which may reasonably expected to be found (in this case in soils found in a garage in a London, urban context) (Regina vs. Gallagher 1998).

\section{The Nature and Practice of Forensic Sediment Analysis}


The nature and practice of forensic geoscience incorporates the requirement to explain, reconstruct or predict provenance of a soil or scene. There are four strands intrinsic to achieving this aim:

1. The nature of the enquiry.

2. The practice of analysis.

3. The interpretation of results.

4. The presentation of results.

\section{The nature of the enquiry (what we do)}

The nature of forensic soil and sediment analysis will depend on the spatial scale with which the investigation is concerned. At the macro-scale, electromagnetic surveying and ground penetrating radar can be used to search for burial sites, as can aerial photography and landscape interpretation, in addition to forensic remote sensing which has also been used in environmental forensic work ( Ruffell and McKinley 2005).

At the micro-scale, the physical, chemical and biological characteristics of a relevant soil/sediment sample (as outlined in figure 1) can be analysed to provide descriptive results, which in some cases can be diagnostic and/or exclusionary (Bull et al. 2004). Such analysis can then aid the investigator in making comparisons between two samples which can, in turn, be interpreted to provide an insight into the reconstruction of a crime. At this scale of enquiry there are generally two types of forensic investigation. Firstly, those that require comparisons to be made between samples in order to assess whether it is possible to exclude samples from having a similar provenance and secondly, those that require the analysis of a particular sample to be made with the purpose of predicting its provenance. Examples of these two different types of investigation can be found in (Morgan et al in press exemplifies the former type of investigation, and Brown et al 2002 exemplifies the latter).

\section{The practice of analysis (how we do it)}


The first stage in any forensic enquiry dealing with soils/sediments is to ensure that appropriate samples are taken from the suspect, the scene and/or exclusion sites. Only if samples representative of the source material are taken can any meaningful analysis be conducted. These problems are universal to both forensic sediment analysis and geoscience (Gilbert and Pulsipher 2005). Indeed, Warren (2005: 23) concludes '... any bias in sample collection...combined with the inherent heterogeneity in the environment and uncertainty in the measurement process can result in an incorrect conclusion'. This will inevitably lead to statistical interpretations which '...may lead to mis-informed conclusions and consequent (and perhaps costly) decisions' (Nocerino et al 2005: 35). Whether the investigation is commercial or criminal makes no difference to the potential for cost to be incurred, it will only dictate the form which that cost may take.

A particularly important aspect of sampling procedures is to ensure that when samples are taken, they are taken in such a way as to be directly comparable with the other soil/sediment samples involved in the case. Morgan and Bull (2006) highlight this potential pitfall in sample acquisition for a case involving a badger sett that had been dug up. A trace soil sample (of the order of grams) was available from the footwear of the suspect, however, the comparator soil sample taken from the crime scene was a bulk sample (of the order of a kilogram or more). It was established through particle size analysis that this sample was comprised of soil from different horizons in the profile and hence this additional complexity had to be taken into account when comparing it with the surficial material taken from the footwear.

The type of analysis undertaken on the soil/sediment samples in forensic enquiry must be dependent on a number of factors. Firstly, the answers that are sought of the sample will influence the type of analyses which are undertaken. In a 'seek and find' predictive investigation the mineralogy of a sample may yield far more useful results for establishing provenance than colour analysis. Conversely, in a particular case of exclusion, colour may prove to be a highly discriminatory form of analysis.

Secondly, the size of the sample may well dictate which analytical techniques are appropriate and possible, and certainly will influence the order in which those techniques are applied. In the geosciences it has been popular to provide sequential 
guides for sediment analysis (Lewis and McConchie 1994). However, in forensic soil/sediment investigation, the fact that there is often only a trace amount of sample available for analysis will impact upon the techniques which are chosen and this will often rule out the use of destructive techniques (those forms of analysis that effectively destroy the sample during analysis, such as AAS and ICP), at least until all other analyses have been undertaken (Palenik's sequence in Murray and Tedrow 1993 and Murray and Solebello 2002). Furthermore, each case should be approached individually in order that the samples yield as much information as possible. The method for achieving this (including the number and order of analytical techniques applied to the soil/sediment samples) will, of course, vary from case to case. It must be accepted that it is better to use fewer techniques and to reproduce the results through a series of different experimental runs than to use many techniques with no repeated checks. It is also conventional and wise, in forensic analysis, for at least half the sample to be left in its original state in order that other scientists may be able to check the findings or undertake other analyses.

Thirdly, the nature of the forensic soil/sediment sample will have a great impact on which analytical techniques will provide meaningful results and therefore, which techniques will be pertinent to an investigation. Anthropogenic-derived samples, such as those taken from a suspect's clothing, footwear or vehicle, are likely to contain materials from a number of different sources (pre-, syn- and post-forensic event). As such, samples from these kinds of recipient mediums will tend to be 'admixtures' or 'contaminated'. It cannot be stressed enough that any technique which requires the homogenisation of a sample will not be able to identify where mixing of soil/sediment from different sources has occurred. Therefore, when comparisons are made between such 'anthropogenic' samples and more 'natural' samples (such as those from a crime scene), there is potential for false-negative or false-positive interpretations of the analysis to be reached. It is therefore very important to be aware of the type of sample under consideration and to tailor the suite of analytical techniques applied to that sample with due care.

Fourthly, a further aspect of soil/sediment sample analysis in forensic enquiry is that of the persistence of transferred forensic materials. It is important to be aware that when such materials are transferred, the nature and conditions of that transfer and the 
nature of the recipient medium will all affect how long the materials will be preserved. Bull et al. (2006) provide extensive experimentation to demonstrate the ability of trace particulates (such as clay, pollen and a variety of anthropogenicderived materials) to persist on clothing. In forensic analysis therefore, it is important to be aware of the time-frames of persistence of particular types of trace material, to assess whether a particular type of evidence is worth looking for in a forensic sample. Indeed, an awareness of these time-frames can aid in the interpretation of any analytical results derived from such samples.

\section{The interpretation of results}

'...Physical evidence cannot be wrong; it cannot perjure itself; it cannot be wholly absent. Only in its interpretation can there be error. Only human failure to find, study and understand it can diminish its value' (Kirk 1974: 2)

Perhaps a fundamental difference between the interpretation of geoforensic results and those of geomorphological and geological studies is as outlined in Kirk (1974) above, tempered with the consideration that if the interpretation of the evidence is wrong in forensic analysis then this may well lead to a miscarriage of justice. We have already identified that the forensic opinion may be based on personal experience and so it is ever more important that the interpretation of the results in forensic analysis is couched within a formula of set principles or precepts (Evett 1991).

A further problem in the interpretation of results is documented by Stoney (1991) and contends that a comprehensive and quantitative treatment of transfer evidence in forensic studies will be elusive because there cannot be a completely reliable and relevant database to evaluate the data generated from analysis of samples. This is due not only to the necessity for databases to apply individually to both the bulk source sample and the transferred trace sample, but also to the requirement for each sample to be evaluated for the specific environments in which the materials are found. Indeed, while relatively simple statistical methods can be applied to the data generated from sample analysis (Gettinby 1991: 156-162), they are unable to incorporate the range of issues that arise in actual casework. 
Statistical measures can be used to interpret the results derived from analysis, but great care must be taken to ensure that erroneous conclusions are avoided. The 'defenders fallacy' (Thompson and Schumann 1987) highlights the potential for statistics to manipulate the data to provide the required interpretation. Aitken (1995: 38-9) presents the following: 'The scenario outlined is that a rare blood type (found in $1 \%$ of the population) is found at the scene of a crime. In a city of 200,000 people, it would be expected that the blood type was found in approximately 2000 people. The defence could argue that the blood evidence found at the scene merely shows that the suspect is 1 of 2000 people in the city who could have committed the crime and that such a small probability has little relevance for proving the guilt of the suspect. However, in contrast, it could be argued that before the evidence of the blood test was available the suspect had a probability of only 1 in 200,000 of being guilty (based solely on this evidence). The effect of the blood test evidence was to increase this probability such that the blood evidence is 100 times more likely if the suspect is guilty than if he is innocent'. Even quantitative statistical 'testing' of the data is open to manipulation depending on the outcome that is desired; the same raw data can be massaged to tell two stories.

The Bayesian approach is considered to be a useful way to approach evidential data in forensic investigations (Evett 1991) as it attempts to incorporate the auxiliary issues surrounding the evidence. In every forensic case two competing hypotheses are considered, generally that $\mathrm{A}$, the defendant committed the crime and $\underline{\mathrm{A}}$, the defendant did not commit the crime. The scientific evidence will impact the odds of A or $\underline{A}$ being true and Bayes' theorem tells us that the odds on A after the scientific evidence is taken into account are the odds before the scientific evidence multiplied by the factor which is known as the likelihood ratio. The role of the forensic geoscientist is therefore to develop the likelihood ratio in order to give the right weight to the results which are presented to the court; i.e. 'what is the probability of the evidence given A?' and 'what is the probability of the evidence given $\underline{A}$ ?'

The highly complex nature of interpreting the results generated from the analysis of forensic samples leads us to the issue of the quest to automate such analysis. Uncertainty must be dealt with in any interpretation of soil/sediment evidence, particularly as there are, as yet, no sufficiently comprehensive databases within which 
to fully evaluate the results of analysis. At this stage it does not seem possible to assign the task of interpreting such data to fully automated system similar to those of the national DNA database. At best, the interpretation of soil/sediment evidence can be semi-quantitative since to go down the fully automated route risks the possibilities of important auxiliary factors not being taken into account. The most obvious of these factors would appear to be the issue of homogenisation and the inability to then identify pre-, syn- or post-forensic event mixing of soils/sediments in a sample.

\section{The presentation of results}

It is of great importance that the results of any analysis of forensic samples are presented to the court in a fair way which takes into account as many of the auxiliary factors as possible. It is not the role of the geoscientist to proffer any opinion as to the guilt or otherwise of the defendant, rather it is their job to comment and interpret the results derived from the analysis of the evidential samples. The evidence that is presented to the court should be the same regardless of whether the forensic geoscientist is working for the defence or the prosecution. With regard to the use of statistics to aid the interpretation of their data, some writers have gone one step further to suggest that ' ...the use of statistical tests should be carried out by professionals who not only have a proper understanding of statistical analytical procedures but also understand when the resulting 'numbers' have true statistical significance. Under most circumstances a jury will not understand the actual procedures. Therefore, presentation of statistical results to a jury, while useful to the scientist, should generally be avoided.' (Isphording 2004: 287-8)

Furthermore, it is considered even more desirable if the presentation of analytical results to the court is made by a number of independent testimonies. This will aid the fight against bias and manipulation of data, and help to establish the true weight of the evidence being presented.

\section{Conclusions}

Throughout this review of the basic philosophy and the nature and practice of forensic sediment analysis and its recent evolution, we have argued that the philosophy of 
forensic sediment analysis is fundamentally different to that of conventional geological and sediment analyses for a number of reasons which are summarised below.

- The practice of forensic geoscience must take into account the necessity for any samples to be representative, and for samples to be comparable. Naturally-sourced and anthropogenically derived provenances must be identified and therefore, different types of samples will require different analytical approaches. Every case will have different auxiliary factors impinging on it which may affect the analytical procedures adopted.

- Geoforensic analysis of soils/sediments involves comparison between samples and their comparators. The comparison is a not absolute. Forensic geoscientists have to deal with exclusion within the framework of sample variability.

- The interpretation of analytical results must be done with extreme caution and with an awareness of the impinging auxiliary factors specific to the case and samples in question.

- The possibility of false-positive or false-negative results is real. The issue of pre-, syn- or post-event contamination within a very short period of time needs special consideration.

- Databases are needed for the evaluation of results derived from soil/sediment analysis. Detailed databases at the level required by some case scenarios do not exist.

- Statistical tests must be undertaken with great caution, and perhaps by experts who can accurately interpret the results. Such tests may seek to take likelihood ratios and probability into account. There is no such thing as simple probability. Furthermore, a persuasive argument can be presented to suggest that statistical 'numbers' should not be presented to the jury at all.

- The development of teams working independently from each other using independent techniques is desirable for the presentation of evidence to the court.

- Since speculative research papers are not used to support geomorphological or geological contractual work (slope failure, environmental assessment etc.) the 
proof is in the practical 'pudding', so to speak. In the law, the proof is a subjective opinion by an expert witness which is to be considered by the jury following lead by the judge. As such, speculation has no place in forensic geoscience enquiry. Indeed, speculation has no place in a court of law. In the case Regina vs. Park (2004) the judge in final direction to the jury stated '...you must be careful in distinguishing between arriving at conclusions based upon reliable circumstantial evidence, and mere speculation.

Speculation amounts to no more than guessing or making up theories without evidence. In no court of law is that a permissible activity.'

\section{Acknowledgements}

RM acknowledges financial support from the Bruce, Julia and Mortimer May Senior Scholarship at Hertford College Oxford. 
Figure 1 Publications concerning forensic analysis of the constituents of soils: the recent years.

\begin{tabular}{|c|c|c|}
\hline $\begin{array}{l}\text { Type of } \\
\text { Analysis }\end{array}$ & Application & Literature \\
\hline \multirow[t]{6}{*}{ Physical } & Colour & $\begin{array}{l}\text { Jones 1941, Dudley 1975, Janssen } \\
\text { et al. 1983, Sugita and Marumo } \\
\text { 1996, Junger } 1996\end{array}$ \\
\hline & Mineralogy & $\begin{array}{l}\text { Marumo, Nagatsuka and Oba 1988, } \\
\text { Graves 1979, Saferstein } 2001\end{array}$ \\
\hline & Particle size distribution & $\begin{array}{l}\text { Dudley 1977, Wanogho et al. 1985, } \\
\text { Sugita and Marumo 2001, } \\
\text { Chazottes, Brocard and Peyrot } \\
\text { 2004, Morgan and Bull in press }\end{array}$ \\
\hline & Density gradient & $\begin{array}{l}\text { Chaperlin and Howarth 1983, Goin } \\
\text { and Kirk, 1947-8, Nickolls 1956, } \\
\text { Nute 1975, Petraco and Kubic } 2000\end{array}$ \\
\hline & Heavy minerals & \\
\hline & S.E.M and surface texture analysis & $\begin{array}{l}\text { Korda, MacDonell and Williams } \\
\text { 1970, Fitzpatrick and Thornton } \\
\text { 1975, Bull and Morgan 2006, Bull } \\
\text { et al 2005 }\end{array}$ \\
\hline \multirow[t]{5}{*}{ Chemical } & Elemental variability & Jarvis, Wilson and James 2003 \\
\hline & Main and trace elements & Linderholm and Lundberg 1994 \\
\hline & Geochemistry & $\begin{array}{l}\text { Rawlins and Cave 2003, Bull et al. } \\
2004\end{array}$ \\
\hline & Chromatography & Siegel and Precord 1985 \\
\hline & Organic content & $\begin{array}{l}\text { Cox et al. 2000, Thornton and } \\
\text { McLaren } 1975\end{array}$ \\
\hline \multirow[t]{4}{*}{ Biological } & Pollen & $\begin{array}{l}\text { Bruce and Dettmann 1996, Bryant } \\
\text { 1990, Bryant, Jones and Mildenhall } \\
\text { 1990,1996, Bryant and Mildenhall } \\
\text { 1998, Eyring 1996, Horrocks et al. } \\
\text { 1998, Horrocks, Coulson and Walsh } \\
\text { 1998,1999, Horrocks and Walsh } \\
\text { 1998,1999, 2001, Horrocks 2004, } \\
\text { Mildenhall 1988,1990, 1992, } \\
\text { Mildenhall and Milne 2000,Milne } \\
1997\end{array}$ \\
\hline & Enzymatic classification & Thornton and McLaren 1975 \\
\hline & Bacterial DNA & Horswell et al. 2002 \\
\hline & Plant wax signatures & Dawson et al. 2003 \\
\hline \multirow[t]{4}{*}{ Combined } & Palynology and mineralogy & Brown 2000, 2002 \\
\hline & $\begin{array}{l}\text { Median particle size, modal class interval of } \\
\text { particle size and organic matter }\end{array}$ & Wanogho et al. 1985 \\
\hline & $\begin{array}{l}\text { Mineralogy, particle size, and biological } \\
\text { factors such as plant fragments, diatoms and } \\
\text { pollen. }\end{array}$ & Hunter et al. 2001 \\
\hline & $\begin{array}{l}\text { Sand, soil, building and road materials vegetal } \\
\text { fragments, paint and fibres }\end{array}$ & Lombardi 1999 \\
\hline
\end{tabular}




\section{References}

Aitken, C. G. G. and Stoney, D. A 1991 The Use Of Statistics in Forensic Science. London: Ellis Horwood Limited. (242pp)

Aitken, C. G. G. 1995 Statistics and the evaluation of evidence for forensic scientists. Chichester: John Wiley and Sons Ltd. (260pp)

BBC news 2005 Trial expert witnesses reviewed. Available online at http://news.bbc.co.uk/1/hi/uk/4317926.stm

Beavan, C. 2001: Fingerprints. Fourth Estate. London. (232pp)

Beh, P. S. L. (ed) 2005 Justice through science. $17^{\text {th }}$ Meeting of the International Association of Forensic Sciences, August 2005, Hong Kong, China. (pp479)

Berg, S. O. 1970: Sherlock Holmes: Father of scientific crime detection. Journal of Criminal Law, Criminology and Police Science 61 (3): 446-452

Brown, T. 2000: Going to Ground. Police Review ( $4^{\text {th }}$ February Edition) p18-20

Brown AG, Smith A, Elmhurst O. 2002: The combined use of pollen and soil analyses in a search and subsequent murder investigation. Journal of Forensic Sciences 47(3):614-618

Bruce, R. and Dettmann, M. 1996: Palynological analyses of Australian surface soils and their potential use on forensic science. Forensic Science International 81 p77-94 Bryant, V. M. Jr 1989: Pollen: Nature's fingerprints of plants. 1990 Yearbook of science and the future, Encyclopedia Britannica, Chicago, Illinois pp 92-111 Bryant, V. M. Jr, Jones, J. G. and Mildenhall, D. C. 1990: Forensic Palynology in the United States of America. Palynology 14:193-208. Available at http://www.crimeandclues.com/palynologyus.htm Bryant, V. M., Jones, J. G. and Mildenhall, D. C. 1996: Studies in forensic palynology. Chapter 23G in Jansonius, J and McGregor, D. C. (ed) Palynology: 
principles and applications. American Association of stratigraphic palynologists Foundation vol 3 p957 - 959

Bryant, V. and Mildenhall, D. 1998: Forensic Palynology: a new way to catch crooks. In Bryant and Wrenn (eds) New Development in Palynomorph Sampling, Extraction ad Analysis. American Association of Stratigraphic Palynologists Foundation Contributions Series No. 33, p145-155. Available online at $\underline{\text { http://www.crimeandclues.com/pollen/htm }}$

Bull, P. A. 1981: Environmental reconstruction by scanning electron microscopy. Progress in Physical Geography 5 (3):368-397

Bull, P. A., Morgan, R. M., Wilson, H. E. and Dunkerley, S. 2004: Multi-technique comparison of source and primary transfer soil samples: an experimental investigation' by D Croft and K Pye [1]. A Comment. Science and Justice 44(3):173-176

Bull, P. A., Morgan, R. M., Dunkerley, S. and Wilson, H. E. 2005: 'SEM-EDS analysis and discrimination of forensic soil' by Cengiz et al. 2004 [1]. A comment. Forensic Science International in press.

Bull, P. A. and Morgan, R. M. 2005: Always be careful of a book of matches. Review of Forensic Geoscience: Principles, Techniques and Applications. Edited by K. Pye and D. J. Croft. Geological Society Special Publication 232. Science and Justice 45(3):

Bull, P. A. and Morgan, R. M. 2006: Sediment Fingerprints: A forensic technique using quartz sand grains. Science and Justice 46 in press.

Bull, P. A., Morgan, R. M., Sagovsky, A., Brent, C. and Hughes, G. J. A. The transfer and persistence of trace particulates: experimental studies using clothing fabrics. Science and Justice submitted*** 
Campbell, M. 2001: The pocket essential Sherlock Holmes. Pocket Essentials. (95pp)

Carita, E. J. 2005: Classical and Future DNA typing technologies for Plants. In Miller

Coyle, H. (ed) Forensic Botany: Principles and Applications to Criminal Casework.

CRC Press 253-274

Chaperlin, K. and Howarth, P. S. 1983: Soil Comparison by the Density Gradient Method - A Review and Evaluation. Forensic Science International 23: 161-177.

Chazottes,V., Brocard, C. and Peyrot, B. 2004: Particle size analysis of soils under simulated sceneof crime conditions: the interest of multivariate analyses. Forensic Science International 140, Issues 2-3 :159-166

Clemens, S. 1894: The Tragedy of Pudd'nhead Wilson. (reprinted 2002) Indypublish.com,US (160pp)

Cox, R. J., Peterson, H. L., Young, J., Cusik, C. and Espinoza, E. O. 2000: Forensic analysis of soil organic by FTIR. Forensic Science International 108(2)107-116

Dawson, L. A., Towers, W., Mayes, R. W., Hillier, S., Fraser, A. Craig, J. and Waterhouse, E. C. 2003: Use of Plant wax signatures in understanding soils. Proceedings of the Clay Minerals Group of the Mineralogical Society and the Forensic Science Society - Trace Metals, Isotopes and Minerals in Forensic Science $200330^{\text {th }}$ October

Dudley, R. J. 1977: The Particle Size Analysis of Soils and its Use in Forensic Science - The Determination of Particle size Distribution Within the Silt and Sand Fractions. Journal of the Forensic Science Society 16:219-229.

Dudley, R. J. 1975: The Use of Color in the Discrimination Between Soils. Journal of the Forensic Science Society 15 (3):209-218.

Evett, I. W. 1991 Interpretation: a personal odyssey. In Aitken, C. G. G. and Stoney, D. A (eds) 1991 The Use Of Statistics in Forensic Science. London: Ellis Horwood Limited. (242pp) 
Eyring, M. B. 1996: Soil pollen analysis from a forensic point of view. Microscope $44(2): 81-97$

Fitzpatrick, F. and Thornton, J.I. 1975: The Forensic Characterization of sand. Journal of Forensic Science 20: 460-475

Freeman, A. R. 1916: John Thorndyke's cases. Chatto and Windus, London (288pp) Freeman, R. Austin 1925: The shadow of the wolf. Hodder and Stoughton, London (320pp)

Gettinby, G. Forensic identification of soil using statistical models. In Aitken, C. G. G. and Stoney, D. A 1991 The Use Of Statistics in Forensic Science. London: Ellis Horwood Limited. (242pp) (156-162)

Gilbert, R. O. and Pulsipher, B. A. 2005 Role of Sampling Designs in Obtaining Representative Data. Environmental Forensic 6:27-33

Goin, L. J. and Kirk, P.L. 1947: Application of Microchemical techniques: identity of soil samples. Journal of Criminal Law and Criminology 38:267-291

Graves, W. J. 1979: A mineralogical soil classification technique for the forensic scientist. Journal of Forensic Sciences 24 (2):323-338

Gross, H. 1893: Manual for examining magistrates. (now published under the title Criminal Investigaton Sweet \& M (1962)).

Horrocks, M. 2004: Sub-sampling and preparing forensic samples for pollen analysis. Journal of Forensic Sciences 49(5) p1024-1027

Horrocks, M., Coulson S. A., and Walsh K.A. J. 1998: Forensic Palynology: variation in the pollen count of soil surface samples. Journal of Forensic Sciences 43(2) p320-23 
Horrocks, M., Coulson, S. A. and Walsh, K. A. J. 1999: Forensic palynology: variation in the pollen content of soil on shoes and in shoeprints in soil. Journal of Forensic Science 44 (1) 119-122

Horrocks, M. and Walsh, K. A. J. 1999: Fine resolution of pollen patterns in limited space: Differentiating a crime scene from an alibi scene seven metres apart. Journal of Forensic Science 44(2) 417-420

Horrocks, M. and Walsh, K. A. J. 2001: Pollen on grass clippings: putting the suspect at the scene of the crime. Journal of Forensic Science 46(4) 947-949

Horrocks, M. and Walsh, K. A. J. 1998: Forensic palynology: assessing the value of the evidence. Review of Palaeobotany and Palynology Special Edition: New Frontiers in Palynology 103(1-2):69-74

Horswell J, Cordiner SJ, Maas EW, Martin TM, Sutherland BW, and Speir TW 2002: Forensic comparison of soils by bacterial community NDA profiling. Journal of Forensic Sciences 47(2):350-353

Houck, M. 2001: Mute Witness:Trace Evidence Analysis. London: Academic Press. Houck, M. 2003: Trace Evidence Analysis: More Cases in Mute Witnesses. Academic Press Inc.(London) Ltd

Hunter, J.R. et al. 2001: Forensic Archaeology, forensic anthropology and human rights in Europe. Science and Justice 41(3):173-178

Ioannidis, J. P. A. 2005: Why most published research findings are false. Public Library of Science Medicine August 20052 (8): 0696-0701 (available at www.plosmedicine.org)

Isphording, W. C. 2004 Statistics in court: the right and wrong ways. In Pye, K. and Croft, D.J. (Eds.) 2004: Forensic Geoscience - Principles, Techniques and 
Applications. Geological Society Special Publication No. 232, Geological Society Publishing House, Bath. (318pp)

Janssen, D. W., Ruhf, W. A. and Prichard, W. W. 1983: Use of clay for soil colour comparisons. Journal of Forensic Sciences 28:773 - 776

Jarvis, K. E., Wilson, H. E. and James, S. L. 2003: Assessing element variability in small soil samples taken during forensic investigation. Proceedings of the Clay Minerals Group of the Mineralogical Society and the Forensic Science Society - Trace Metals, Isotopes and Minerals in Forensic Science 2003 30 ${ }^{\text {th }}$ October Jones, J. 1941: The identification of sand. Police Journal 14(2):209-215

Junger, E. P. 1996: Assessing the unique characteristics of close-proximity soil samples: just how useful is soil evidence? Journal of Forensic Science 41(1): 27-34

Kirk, P. L. 1949-1950: Microscopic Evidence - Its use in the Investigation of Crime.

The Journal of Criminal Law and Criminology 40:364-366

Kirk, P. L. 1963: The ontogeny of criminalistics. J. Criminal Law, Criminology and Police Science 54:235-238

Kirk, P. L. 1974: Crime Investigation ( $2^{\text {nd }}$ ed) New York: Wiley (526pp)

Kleiner, K. 2005: Most scientific papers are probably wrong. New Scientist $30^{\text {th }}$ August 2005 available at http://www.newscientist.com/article.ns?id=dn7915

Korda, E. J., MacDonell, H. L. and Williams, J. P. 1970: Forensic Applications of the Scanning Electron Microscope. Journal of Criminal law, Criminology and Police Science 61(3) 453-458

Krinsley,D. H. and Doornkamp, J. C. 1973: Atlas of quartz sand surface textures. Cambridge University Press (91pp).

Lewis, D. W. and McConchie, D. 1994 Analytical Sedimentology. Chapman and Hall (197pp). 
Linderholm, J. and Lundberg, E. 1994: Chemical characterisation of various archaeological soil samples using main and trace elements determined by inductively coupled plasma atomic emission spectrometry. Journal of Archaeological Science 21(3):303-314

Locard, E. 1930: Analyses of dust traces parts I, II and III. American Journal of Police Science 1: 276-298, 401-418 and 496-514.

Lombardi, G. 1999: The Contribution of Forensic geology and Other Trace Evidence Analysis to the Investigation of the Killing of Italian Prime Minister Aldo Moro Journal of Forensic Sciences 44(3):634-642

Mahaney, W. C. 2002: Atlas of sand grain surface textures and applications. Oxford University Press, Inc. (237pp)

Marumo, Y., Nagatsuka, S., and Oba, Y. 1988: Rapid Clay Mineralogical Analysis for Forensic Science Investigation - Clay Mineralogy Over The Short Distances. Journal of Forensic Sciences 33(6):1360-1367

Mildenhall, D. C. 1988: Deer Velvet and palynology: an example of the use of forensic palynology in New Zealand. Tuatara 30:1-11.

Mildenhall 1990: Forensic Palynology in New Zealand. Review of Palaeobotany and Palynology 64 p227-234

Mildenhall, D. C. 1992: Forensic Palynology. Geological Society of New Zealand Newsletter 58:25

Mildenhall and Milne 2000: Forensic Palynology - Nature's Crime Busting Tool. In The CrimTrac $15^{\text {th }}$ International Symposium on the Forensic Sciences.

Milne, L. 1997: Geoscientist - Palynology and Forensic Palynology. http://science/uniserve.edu.au http://science/uniserve.edu.au/faces/milne/milne.html 
Miller Coyle, H. (ed) 2005: Forensic Botany: Principles and Applications to Criminal Casework. CRC Press

Morgan, R. M. and Bull, P.A. 2006 in press: The use of particle size analysis of sediments and soils in forensic enquiry. Science and Justice

Morgan, R. M., Bull, P. A., Wiltshire, P. and Parker, A. J. 2006 in press: The role of forensic geoscience in wildlife crime detection. Forensic Science International Moore, P., Webb, J. and Collinson, M. 1991: Pollen analysis. Oxford: Blackwell Science Ltd.

Murray, R. C. and Solebello, L. P. 2002: In Saferstein, R. (ed) Forensic Science Handbook volume I. Prentice-Hall. Upper Saddle River, New Jersey.(pp767)

Murray, R. C. and Tedrow, J. C. F. 1992: Forensic Geology. Prentice-Hall, Inc.

Murray, R. C. and Tedrow, J. C. F. 1975: Forensic Geology: Earth Science and Criminal Investigation. Rutgers University Press.

Nickolls, L. C. 1956: The Scientific Investigation of Crime. London: Butterworth \& Co. Ltd

Nocerino, J. M., Schumacher, B. A. and Dary, C. C. 2005: Role of Laboratory Sampling Devices and Laboratory Subsampling Methods in Representative Sampling Strategies. Environmental Forensic 6:35-44

Nute, H. D. 1975: Improved density gradient system for forensic science soil studies. Journal of Forensic Sciences 20: 668-673

Petraco N, Kubic T. 2000: A density gradient technique for use in forensic soil analysis. Journal of Forensic Sciences 45(4):872-873

Pye, K. and Croft, D.J. (Eds.) 2004: Forensic Geoscience - Principles, Techniques and Applications. Geological Society Special Publication No. 232, Geological Society Publishing House, Bath. (318pp) 
Regina vs. Gallagher 1998 Woolwich Crown Court. January 1998.

Regina vs. Park 2004 Manchester Crown Court. December 2004.

Rawlins, B. G. and Cave, M. 2003: Investigating multi-element soil geochemical signatures and their potential for use in forensic studies. Proceedings of the Clay Minerals Group of the Mineralogical Society and the Forensic Science Society - Trace Metals, Isotopes and Minerals in Forensic Science $200330^{\text {th }}$ October

Ruffell, A. and McKinley, J. 2005: Forensic Geoscience: applications of geology, geomorphology and geophysics to criminal investigations. Earth-Science Reviews 69:235-247

Saferstein, R. 2004: Criminalistics: An Introduction to Forensic Science $6^{\text {th }}$ ed. Upper Saddle River, N. J.: Prentice Hall. (pp588)

Sarjeant, W. A. S. 1994: Detectives and Geology in Fiction - 1: Holmes and Thorndyke. Geology Today Nov-Dec: 228-231

Sengoopta, C. 2004: Imprint of the Raj. Macmillan (234pp)

Siegel, J. A. and Precord, C. 1985: The Analysis of Soil Samples by Reverse PhaseHigh Performance Liquid Chromatography Using Wavelength Ratioing. Journal of Forensic Sciences 30(2):511-525

Stoney, D. A. 1991 Transfer Evidence. In Aitken, C. G. G. and Stoney, D. A (eds) 1991 The Use Of Statistics in Forensic Science. London: Ellis Horwood Limited. (242pp).

Sugita, R. and Marumo, Y. 1996: Validity of colour examination for forensic soil identification. Forensic Science International 83: 201-210

Sugita, R. and Marumo, Y. 2001: Screening of soil evidence by a combination of simple techniques: validity of particle size distribution. Forensic Science International 122: 155-158 
Thompson, W. C. and Schumann, E. L. 1987: Interpretation of statistical evidence in criminal trials. Law and Human Behaviour 11(3): 167-187

Thornton and McLaren 1975: Enzymatic characterisation of soil evidence. Journal of Forensic Sciences 20: 674 - 692

Townley, L. and Ede, R. 2003: Forensic practice in criminal cases. Law Society

Publications (504pp)

Walls, H.J. 1968: Forensic Science. London: Sweet and Maxwell.

Wanogho, S. and Caddy, B. 1985: A Statistical Method for Assessing Soil

Comparisons. Journal of Forensic Sciences 30(3): 864-873

Wanogho S, Gettinby G, Caddy B, Robertson J. 1989: Determination of Particle Size

Distribution of Soils in Forensic Science Using Classical and Modern Instrumental

Methods. Journal of Forensic Sciences 34(4):823-835

Watson, A. 2000: A new breed of High-Tech Detectives. Science 289: 850-854

Warren, J. 2005 Representativeness of Environmental Samples. Environmental Forensic 6:21-25

Wiltshire, P. 2002: Environmental Profiling and Forensic Palynology. www.bahid.org 